\title{
PROPOSTA DE GESTÃO AMBIENTAL E DETECÇÃO DE DANOS SOCIOAMBIENTAIS DO PARQUE ESTADUAL DO RIO DA ONÇA - PR E ÁREA DE ENTORNO'.
}

\section{Leandro José Ribeiro Guimarães ${ }^{2}$}

A implementação de parques, seja qual for a categoria (Federal, Estadual, Municipal) envolve uma série de estudos de viabilidade. Entretanto, após seu estabelecimento, uma fiscalização ativa e profunda é necessária, especialmente quando falamos em parques abertos à visitação e situados em locais de grande concentração de população, como é o caso do Parque Estadual do Rio da Onça, em Matinhos. Este município apresenta um fluxo de pessoas elevado, especialmente no verão, sobrecarregando todo o sistema de infra-estrutura da cidade. A proposta de gestão ambiental no Parque Estadual rio da Onça se faz de forma a estabelecer diretrizes para a normalização, revitalização, e utilização racional e sustentada dos recursos da bacia, bem como avaliação dos impactos socioambientais da área de entorno. É de fundamental importância seu reconhecimento para futuras elaborações de estudos como zonas de amortecimento e corredores ecológicos. São influências de fatores degradantes à região as formas com que o solo é utilizado, além de se fazer necessária a compreensão dos índices de qualidade de água, como DBO (demanda bioquímica de oxigênio), índices de coliformes fecais e substâncias tóxicas, ao longo da bacia do rio da Onça, uma das formas de se compreender o grau de deteriorização na região.

PALAVRAS-CHAVE: bacias hidrográficas; gestão ambiental; parque estadual.

\footnotetext{
${ }^{1}$ Orientador: Prof. .Dr. Leonardo José Cordeiro Santos

${ }^{2}$ Mestrando em Geografia (UFPR) - e-mail: leandrojrguimaraes@hotmail.com
} 